\title{
Functional constituents and quality stability according to storage conditions of chaga mushroom extract
}

\author{
Da-Hyun Park ${ }^{1}$, Ji-Hong Hwang ${ }^{1}$, Yong-Jin Jeong ${ }^{1,2 *}$ \\ ${ }^{1}$ KMF Co., Ltd., Daegu 41065, Korea \\ ${ }^{2}$ Department of Food Science and Technology, Keimyung University, Daegu 42601, Korea
}

\section{차가버섯 추출물의 저장조건에 따른 기능성분 변화 및 품질안정성 \\ 박다현 ${ }^{1}$ - 황지홍 ${ }^{1}$ - 정용진 ${ }^{1,2 *}$ \\ ${ }^{1}$ (주)케이엠에프, ${ }^{2}$ 계명대학교 식품가공학과}

\begin{abstract}
This study investigated the effect of temperature on functional constituents and quality stability in chaga mushroom extract during an eight-week storage period. Soluble solid and total polyphenol content $(26 \mathrm{mg} / \mathrm{mL})$ showed no significant changes during storage, whereas pH values increased from 5.38 to $5.46(p<0.05)$. DPPH radical-scavenging activity exceeded $70 \%$ regardless of storage conditions; in contrast, ABTS radical-scavenging activity declined by $6.2 \%, 7.1 \%$, and $7.9 \%$ after eight weeks of storage at $25^{\circ} \mathrm{C}, 35^{\circ} \mathrm{C}$, and $45^{\circ} \mathrm{C}$, respectively. The $\beta$-glucan content $(2.58 \%)$ was stable at $-20^{\circ} \mathrm{C}$ and $25^{\circ} \mathrm{C}$, but it significantly declined after 6 weeks of storage at high temperatures $(p<0.05)$. Similarly, the betulin content $(12 \mu \mathrm{g} / \mathrm{mL})$ was constant at $-20^{\circ} \mathrm{C}$. Microbial growth was not detected in the extract at any point during the storage period, owing to heat treatment $\left(95^{\circ} \mathrm{C}\right.$ for $\left.10 \mathrm{~min}\right)$. Overall, the results on functional constituents and quality stability of chaga mushroom extract suggest that storage conditions may affect the chemical attributes of the extract.
\end{abstract}

Key words : chaga mushroom extract, storage, functional constituents, quality changes, quality stability

\section{서 론}

차가버섯(Chaga, Inonotus obliquus)은 담자균류(Basidiomycetes)의 소나무비늘버섯과(Hymenochaetaceae)에 속한다. 차가버섯은 다른 버섯과 다르게 기생 균주의 형태로 자작나 무 몸통에 침투하여 자라고, 나무의 영양분을 축적하며 껍질 을 뚫고 점점 외부로 돌출되어 단단한 덩어리 형태로 나무의 표면에 생장하는 특성을 지닌 버섯이다(Kahlos, 1994). 차가 버섯은 16 세기 이후 민간에서 암, 위염, 궤양, 결핵 치료 등에 활용되어 온 것으로 알려져 있다. 차가버섯의 효능에 관한 연구 로는 항결핵 활성(Song 등, 2011), 비장세포 증식능과 cytokine
생성능에 미치는 영향(Kim 등, 2010), 항산화 및 항암효과 (Qi 등, 2013), 면역조절에 미치는 영향(An 등, 2010), 체중증 가 억제 및 지방대사 개선작용(Kim 등, 2016) 등이 보고되고 있으며, 면역활성 다당을 포함한 생리활성물질의 추출조건 최적화에 대한 연구가 수행된 바 있다(Kim 등, 2015).

차가버섯은 다양한 기능성 물질 중 많은 양의 폴리페놀과 플라보노이드를 함유하여 강력한 항산화제로 작용한다고 보 고되었다(Cui 등, 2005). 차가버섯에는 다양한 식이섬유들이 존재하는데, 그중 가장 주목받는 소재는 $\beta$-glucan이다. $\beta$ Glucan은 자연살해세포(natural killer cell)의 활성을 회복시킴 으로 세포면역을 증강시키는 것을 확인함으로써 다양한 암에

*Corresponding author. E-mail : yjjeong@kmu.ac.kr, Phone : +82-10-3501-8808, Fax : +82-53-584-6524

Received 18 June 2020; Revised 28 September 2020; Accepted 29 October 2020.

Copyright (c) The Korean Society of Food Preservation.

This is an Open Access article distributed under the terms of the Creative Commons Attribution Non-Commercial License (http://creativecommons.org/licenses/by-nc/4.0) which permits unrestricted non-commercial use, distribution, and reproduction in any medium, provided the original work is properly cited. 
항암효과를 보인다고 보고되었다(Tabata 등, 1981; Yamamoto 등, 1981). 차가버섯에 함유된 베툴린(betulin)은 therapeutic agent로 유효한 베툴린산(betulinic acid), 베툴론산(betulonic acid) 또는 이들 유도체(their derivatives)의 유기합성(organic synthesis)에 사용되는 원료 물질(starting material)로 많이 사 용되고 있는 과학적 사실이 많이 발표되어 왔다. 다수 논문들 을 통해서 베툴린산은 melanoma(예를 들어 MEL-2, MEL-2 과 MEL-4)에 antitumor activity를 갖고 있다는 과학적 발견 (Pisha 등, 1995)과, 베툴린산이 H9 lymphocytic 세포에서 anti-HIV activity를 가지고 있다는 연구 결과들이 보고되었 다(Fujioka 등, 1994). 또한 Gong 등(2004)은 베툴린을 acyclovir와 혼합 사용한 결과, herpes simplex viruses 등에 antiviral 효과가 있다고 보고되었다.

차가버섯은 단단한 조직으로 인해 버섯 자체로 식용이 불 가능하기 때문에 추출물을 이용하는 것이 일반적이다. 현재 까지 보고되거나 상용화된 차가버섯 추출물 제품은 대부분 분말 제형이며, 액상 제형 제품의 상품화는 매우 드문 실정이 다. 최근 건강 지향적 식품시장의 확대와 $\mathrm{RTD}$ (ready to drink) 음료 시장의 성장에 따라 기능성 버섯 음료의 상품화에 관심이 늘어나고 있다. 이에 본 연구에서는 차가버섯 추출물의 보존안정성을 확인하기 위하여 여러 온도(-20, $\left.25,35,45^{\circ} \mathrm{C}\right)$ 에 서 8 주 동안의 저장기간에 따른 기능성분 변화와 미생물적 품질안정성을 비교 분석하였다.

\section{재료 및 방법}

\section{시료 제조 및 저장 조건}

본 실험에 사용된 차가버섯은 2019년 러시아 시베리아에 서 수입한 것으로서 선별, 수세 및 건조한 버섯을 분말(40 mesh)로 제조하여 시료로 사용하였다. 추출방법은 고압살균 기(autoclave, JSAT-65, JSR, Gongju, Korea)에 건조분말에 정제수 20 배를 가하여 $120^{\circ} \mathrm{C}$ 에서 1 시간 추출하고 여과지 (Whatman No.3)로 여과하여 1차 추출액을 얻었다. 2차 추출 물은 1 차 추출 후 남은 잔사에 20 배의 $50 \%$ 주정을 가하여 실온에서 24시간 침지 추출하고 여과하여 2차 추출액을 얻었 다. 그리고 1,2 차 추출물을 혼합하여 가용성 고형분 함량을 $10{ }^{\circ} \mathrm{Brix}$ 가 되도록 감압 농축하여 실험 시료로 사용하였다.

상기 차가버섯 추출물은 $95^{\circ} \mathrm{C}$ 이상에서 10 분간 살균하고 $20 \mathrm{~mL}$ 유리병에 $10 \mathrm{~mL}$ 씩 각각 주입하여 각각의 실험시료로 제조하였다. 빛이 차단된 조건에서 유통기한 설정 저장 실험 조건으로 실온 유통제품의 유통온도를 고려하여 $25^{\circ} \mathrm{C}, 35^{\circ} \mathrm{C}$ 및 $45^{\circ} \mathrm{C}$ 를 각각 설정하여 각 온도의 항온기에서 보관하였으 며, 냉동 후 해동 상태의 품질안정성을 확인하기 위해 $-20^{\circ} \mathrm{C}$ 를 추가로 설정 보관하였다. 각각의 조건에서 저장된 차가버 섯 추출물은 2 주 간격으로 기능성분 및 미생물적 품질 분석
을 실시하였다.

\section{$\mathrm{pH}$ 및 가용성 고형분 측정}

각각의 조건에서 $20 \mathrm{~mL}$ 유리병에 보관되어 있던 차가버 섯 추출물을 일정량 취하여 $\mathrm{pH}$ 측정은 $\mathrm{pH}$ meter(STARA111, Thermo Fisher Scientific, Waltham, MA, USA)를 이 용하여 반복 실험하였고, 가용성 고형분 함량은 굴절당도계 (PAL-1, ATAGO, Tokyo, Japan)를 사용한 후 측정하여 ${ }^{\circ}$ Brix로 나타내었다.

\section{색도 측정}

차가버섯 추출물 $(20 \mathrm{~mL}$ 유리병)의 저장 중 색도 변화와 직사광선에 의한 영향 여부를 측정하기 위해 2019년 9월부 터 11월까지 8주 동안 각각 암소(대조구)와 햇빛이 잘 드는 실험실 창가(sunlight)에 보관하였다. 암소는 $25^{\circ} \mathrm{C}$ 에 보관되 었고, 실험실 실내 온도는 $20 \pm 5^{\circ} \mathrm{C}$ 의 온도로 유지되었으며, 9 월부터 11 월까지의 평균 일조시간은 6.6시간이었다. 각각의 조건에 보관된 시료를 일정량 취하여 UV-VIS spectrometer (UV-1800, Shimazu, Tokyo, Japan)를 이용하여 색도를 측정 하였으며, UVPC color analysis(Ver.3.10, Shimazu, Tokyo, Japan)에 의해 L(lightness), a(redness) 및 b(yellowness) 값으 로 변환하여 Hunter's color value로 나타내었다. 이때 표준물 질로 사용된 증류수의 $\mathrm{L}, \mathrm{a}, \mathrm{b}$ 값은 각각 $99.99,-0.10$. -0.01이 었으며, 전반적인 색차(overall color difference, $\Delta \mathrm{E}$ )는 아래 계산식을 이용하여 저장조건에 따른 차가버섯 추출물의 색의 변화를 산출하였다.

$$
\Delta \mathrm{E}=\sqrt{\left(L-L^{\prime}\right)^{2}+\left(a-a^{\prime}\right)^{2}+\left(b-b^{\prime}\right)^{2}}
$$

$\mathrm{L}, \mathrm{a}, \mathrm{b}$ : 초기 차가버섯 추출물의 색도 $\mathrm{L}^{\prime}, \mathrm{a}^{\prime}, \mathrm{b}^{\prime}$ : 변화된 차가버섯 추출물의 색도

\section{폴리페놀 함량 측정}

총폴리페놀 함량은 Folin과 Denis(1912)의 방법을 변형하 여 측정하였다. 각 차가버섯 추출물 $0.1 \mathrm{~mL}$ 에 $7 \% \mathrm{Na}_{2} \mathrm{CO}_{3}$ $2.0 \mathrm{~mL}$ 를 가하고 3 분간 정치시켰다. 그 후 $50 \%$ Folin-Denis reagent $0.1 \mathrm{~mL}$ 를 첨가하고 잘 혼합한 뒤 30 분간 암반응을 시킨 후 UV-VIS spectrometer(UV-1800, Shimazu)를 이용하 여 $750 \mathrm{~nm}$ 파장에서 흡광도를 측정하였다. 시료에 포함된 총 폴리페놀 함량은 gallic acid의 표준곡선에 시료의 흡광도 측 정값을 대입하여 농도를 결정하였다.

\section{$\mathrm{DPPH}$ 라디칼 소거능 측정}

$\mathrm{DPPH}(2,2-$ diphenyl-1-picrylhydrazyl) 라디칼 소거활성은 
Blois(1958)의 방법을 변형하여 측정하였다. 항산화 효능에 주로 이용되는 $\mathrm{DPPH}$ 는 분자 내 라디칼을 함유하고 있어 polyhydroxy 방향족 화합물, 방향족 아민류 등에 의해 환원 되며, 이때 라디칼이 소거되어 짙은 자색이 탈색되는 정도를 흡광도를 이용하여 측정하였다. 이때 $99.9 \%$ ethanol에 녹인 $0.2 \mathrm{mM}$ DPPH solution $0.8 \mathrm{~mL}$ 에 각 추출물 $0.2 \mathrm{~mL}$ 를 넣고 10 초간 혼합하였다. 그리고 빛을 차단한 상태에서 30 분간 상온 에서 반응시킨 뒤 UV-VIS spectrometer(UV-1800, Shimazu)를 이용하여 $517 \mathrm{~nm}$ 의 파장에서 흡광도를 측정하였으며, 첨가 구와 비첨가구의 흡광도를 백분율(\%)로 나타내었다.

\section{$\mathrm{ABTS}^{+}$라디컬 소거능 측정}

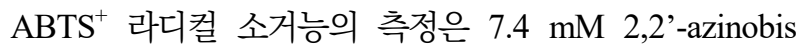
(3-ethylbenzothiazoline-6-sulfonic acid)(ABTS)와 $2.6 \mathrm{mM}$ potassiom persulfate를 혼합한 후 16 시간 반응시켜 $\mathrm{ABTS}^{+}$를 형성시켰다. 사용 전에 ABTS 용액을 희석하고, UV-VIS Spectrometer(UV-1800, Shimazu)를 이용하여 흡광도 734 $\mathrm{nm}$ 에서 값이 $1.000 \pm 0.005$ 가 되게 하여 사용하였다. 희석한 ABTS 혼합용액 $1.0 \mathrm{~mL}$ 에 시료 $0.05 \mathrm{~mL}$ 를 혼합하여 5 분간 반응 후 $734 \mathrm{~nm}$ 에서 흡광도를 측정하였고, 첨가구와 비첨가 구의 흡광도를 백분율(\%)로 나타내었다.

\section{베타글루칸 함량 분석}

베타글루칸( $\beta$-glucan) 함량은 $\beta$-glucan assay kit(Megazyme International Irelend Ltd., Bray, Wicklow, Ireland)를 사용하 여 측정하였고, 차가버섯 추출물은 동결건조하여 분말화 하 였다. 시료 $100 \mathrm{mg}$ 에 $37 \% \mathrm{HCl} 1.5 \mathrm{~mL}$ 를 넣고 $40^{\circ} \mathrm{C}$ 항온수 조에서 45 분간 방치한 후, 증류수 $10 \mathrm{~mL}$ 를 가하고 $100^{\circ} \mathrm{C}$ 항 온수조에서 다시 2 시간 동안 반응시켰다. 반응액을 상온으로 완전히 식힌 후 $2 \mathrm{~N} \mathrm{KOH} 10 \mathrm{~mL}$ 를 가하여 혼합한 후 200 $\mathrm{mM}$ sodium acetate buffer를 가하여 $100 \mathrm{~mL}$ 로 정용하였다. 정용한 시료는 원심분리 $(1,500 \times g, 10$ 분 $)$ 하여 상층액을 얻고, 얻은 상층액 $0.1 \mathrm{~mL}$ 에 exo-1,3 $\beta$-glucanase $(100 \mathrm{U} / \mathrm{mL})$ 와 $\beta$ glucosidase $(20 \mathrm{U} / \mathrm{mL})$ 혼합액 $0.1 \mathrm{~mL}$ 를 첨가한 후 $40^{\circ} \mathrm{C}$ 항 온수조에서 1시간 반응하였다. 이어서 $3 \mathrm{~mL}$ 의 $\mathrm{GOPOD}$ (glucose oxidase/peroxidase)를 넣고 $40^{\circ} \mathrm{C}$ 에서 20 분간 반응 시킨 다음 $510 \mathrm{~nm}$ 파장에서 흡광도를 측정하여 총 글루칸 함량을 구하였다.

알파글루칸( $\alpha$-glucan) 함량은 시료 $100 \mathrm{mg}$ 에 $2 \mathrm{~N} \mathrm{KOH} 2$ $\mathrm{mL}$ 를 넣고 혼합하였다. $1.2 \mathrm{M}$ sodium acetate buffer $8 \mathrm{~mL}$ 를 넣고 amyloglucosidase $1,630 \mathrm{U} / \mathrm{mL}$ 와 invertase $500 \mathrm{U} / \mathrm{mL}$ 용 액을 $0.2 \mathrm{~mL}$ 가하여 $40^{\circ} \mathrm{C}$ 항온수조에서 30 분간 반응시킨 후 원심분리 $(1,500 \times g, 10$ 분)하여 상층액을 얻었다. 상층액 0.1 $\mathrm{mL}$ 에 $200 \mathrm{mM}$ sodium acetate buffer $0.1 \mathrm{~mL}$ 와 GOPOD 시
약 $3 \mathrm{~mL}$ 를 넣고 $40^{\circ} \mathrm{C}$ 에서 20 분간 반응 후 $510 \mathrm{~nm}$ 파장에서 흡광도를 측정하였다. 측정된 총 글루칸과 $\alpha$-glucan의 흡광 도는 glucose 용액을 GOPOD 시약과 반응시킨 반응액의 흡 광도를 이용하여 $\mathrm{g} / 100 \mathrm{~g}$ 값으로 계산하였다. 최종적으로 $\beta-$ glucan 함량은 총 글루칸 함량에서 $\alpha$-glucan 함량을 뺀 값으 로 계산하였다.

\section{베툴린 함량 분석}

베툴린(betulin) 함량 분석을 위한 고속액체크로마토그래 프(high performance liquid chromatograph)는 UV 검출기가 장착된 HPLC(Waters 2487, Waters Co., Miliford, MA, USA)를 사용하였다. 분석 시료의 조제는 추출물을 $0.45 \mu \mathrm{m}$ syringe filter로 여과한 후, 이 중 $100 \mu \mathrm{L}$ 를 $\mathrm{HPLC}$ 에 주입하 였다. 분석 칼럼으로는 Waters Symetry $\mathrm{C}_{18}(250 \times 4.6 \mathrm{~mm}, 4$ $\mu \mathrm{m})$ 을 사용하여 아세토니트릴/물 $(9: 1, \mathrm{v} / \mathrm{v})$ 을 혼합한 용액을 이동상으로 사용하였으며, $1 \mathrm{~mL} / \mathrm{min}$ 유속으로 측정파장은 $210 \mathrm{~nm}$ 로 하여 분석하였다(Holonec 등, 2012). 베툴린 검량 선 작성은 표준품 $2 \mathrm{mg}$ 을 methanol에 녹여 stock solution(2 $\mathrm{mg} / 2 \mathrm{~mL}$ )을 제조한 후 각각 $31.25,62.5,125,250,500$, $1,000 \mu \mathrm{g} / \mathrm{mL}$ 의 농도가 되도록 working solution을 준비하여 검량선을 작성하였고, 시료량과 추출용매의 희석배수를 감안 하여 $\mu \mathrm{g} / 100 \mathrm{~g}$ 으로 환산하였다.

\section{미생물 농도 검사}

저장온도 $-20,25,35$ 및 $45^{\circ} \mathrm{C}$ 에서 각각 8 주 동안 시료를 보관하면서 2주 간격으로 총세균과 대장균군의 농도 변화를 3 회 반복 측정하였다. 시료 $1 \mathrm{~mL}$ 를 무균적으로 채취하여 페 트리필름(3M Petrifilm, 3M Co., St. Paul, MN, USA)에 분주 한 후 일반세균 및 대장균군은 $35^{\circ} \mathrm{C}$ 에서 24-48시간 배양한 후 미생물학적 안전성을 확인하였다.

\section{통계 분석}

실험 결과는 모든 실험을 3 회 반복 측정한 값을 $\mathrm{IBM}$ SPSS Statistics(25, IBM Corp., Armonk, NY, USA) 프로그 램 중에서 기술통계를 실시하여 ‘평균 \pm 표준편차’로 나타내었 고, T-test 및 Duncan's multiple range test로 유의성 검정을 실시하였다 $(\mathrm{p}<0.05)$.

\section{결과 및 고찰}

\section{추출물의 저장 중 $\mathrm{pH}$ 및 가용성 고형분 함량}

식품의 저장 중 $\mathrm{pH}$ 변화는 식품의 부패 현상을 예측하는 지표로서 유용한 수단이 된다(Bhullar 등, 1985). 차가버섯 추출물의 저장 온도 및 기간에 따른 $\mathrm{pH}$ 값은 Table 1 과 같다. 
저장 초기 추출물의 $\mathrm{pH}$ 는 5.33 을 보였으나, 저장 중에는 $\mathrm{pH}$ $5.38-5.46$ 의 범위를 나타내었고, $-20,25-45^{\circ} \mathrm{C}$ 의 온도에서 8 주 동안 저장한 후에는 최종 $\mathrm{pH}$ 5.44-5.45 수준을 나타내었 다. 이같이 저장 조건에 따른 추출물의 $\mathrm{pH}$ 변화는 유의적인 증가였으나 $(\mathrm{p}<0.05)$ 값의 변화는 크지 않았으며, 이와 같은 $\mathrm{pH}$ 값의 미미한 증가는 추출물에 함유된 유기산 등의 감소와 연관이 있을 것으로 예상되었다. 추출물의 가용성 고형분 함 량 변화는 Table 1 에서와 같이 $9.9-10.1{ }^{\circ} \mathrm{Brix}$ 의 범위로써 저 장 온도 및 기간에 따른 유의미한 변화가 없는 것으로 확인되 어 차가버섯 추출물 중 가용성 고형분 함량은 비교적 안정함 을 확인하였다. 한편, 저장 기간 동안 차가버섯 추출물에는 침전물의 생성이 관찰되지 않았으며, 이는 적절한 여과 공정 이 진행된 결과로 사료된다.

\section{추출물의 저장 중 색도 변화}

식품의 색도는 식품의 이화학적 품질을 외관적으로 판단 하는 기준이 되며, 액상 제품의 색도는 유통 중 품질안정성을 나타내는 중요한 품질지표이다. 투명유리병에 포장된 차가버 섯 추출물을 암실(대조구)과 실험실 창가의 직사광선 조건 (sunlight)에 8주 동안 저장하면서 추출물의 색도 $(\mathrm{L}, \mathrm{a}, \mathrm{b}$ 및 $\Delta \mathrm{E})$ 변화를 2 주 간격으로 측정하였다(Table 2). 저장 초 추출 물의 $\mathrm{L}$ (명도) 값은 $4.19, \mathrm{a}$ (적색도) 값은 $-0.03, \mathrm{~b}$ (황색도) 값 은 -0.32 수준으로 비교적 맑고 투명한 색 특성을 보여주었 다. 그러나 저장 기간이 경과할수록 직사광선 조건이 암실 조 건에 비해 $\mathrm{L}, \mathrm{a}, \mathrm{b}$ 값의 변화에서 다소 큰 증감을 나타내었다.
그러나 이상의 색 특성의 변화는 유의적인 수준이 아니었으 며, 저장 기간 중 종합적인 색의 변화를 확인하기 위해 전반 적 색차 $(\Delta \mathrm{E})$ 를 산출해 본 결과, 0.15-0.31 수준으로(trace, 아 주 조금) 8 주 저장 기간 동안 온도와 직사광선의 노출이 차가 버섯 추출물의 색도 변화에 뚜렷한 영향을 미치지 않는 것으 로 나타났다. Chae 등(2012)은 에탄올에 용해시킨 비타민나 무 잎 추출물의 경우 태양광선에 노출되었을 때 추출물의 성 분이 변화가 일어나 흡광도가 크게 감소하였다고 보고하여, 차가버섯 추출물에 비해 비타민나무 잎 추출물은 빛에 더 안 정한 것으로 사료된다.

\section{추출물의 저장 중 폴리페놀 함량 및 항산화성 변화}

페놀성 화합물은 식물계에 널리 분포하는 2 차 대사산물의 하나로서 다양한 구조를 갖는데, 특히 이 중에 phenolic hydroxyl기가 단백질 및 기타 거대 분자들과 결합하는 성질 이 강하여 항산화 등의 다양한 생리활성 기능을 나타낸다. 차 가버섯은 자작나무에서 유래한 다양한 페놀물질을 가지고 있 다고 보고되어 있다(Liang 등, 2009). 차가버섯 추출물의 총 폴리페놀 함량 변화를 분석한 결과는 Fig. 1과 같다. 저장 기 간에 따른 차이는 크지 않았으며, 폴리페놀 함량은 처음 $26.79 \mathrm{mg} / \mathrm{mL}$ 에서 8주 후에는 $26.53-26.37 \mathrm{mg} / \mathrm{mL}$ 로 나타나 유의적인 변화를 나타내지 않았다(p>0.05). Lee 등(2005)은 차가버섯을 $80^{\circ} \mathrm{C}$ 에서 8 시간 진탕 추출하고, 여과한 추출물의 건조 획분을 $1,000 \mathrm{ppm}$ 농도로 조제하였을 때 $263 \mu \mathrm{g} / \mathrm{mL}$ 의 함량이었다고 보고해 본 연구의 결과와 비슷한 총폴리페놀

Table 1. Changes in pH and soluble solid of chaga mushroom extract during storage

\begin{tabular}{|c|c|c|c|c|c|}
\hline & \multirow{2}{*}{$\begin{array}{l}\text { Storage period } \\
\quad \text { (week) }\end{array}$} & \multicolumn{4}{|c|}{ Temperature $\left({ }^{\circ} \mathrm{C}\right)$} \\
\hline & & -20 & 25 & 35 & 45 \\
\hline \multirow{5}{*}{$\mathrm{pH}$} & 0 & $5.33 \pm 0.02^{1) \mathrm{A} 2) \mathrm{d} 3)}$ & $5.33 \pm 0.02^{\mathrm{Ac}}$ & $5.33 \pm 0.02^{\mathrm{Ac}}$ & $5.33 \pm 0.02^{\mathrm{Ac}}$ \\
\hline & 2 & $5.38 \pm 0.01^{\mathrm{Bc}}$ & $5.42 \pm 0.00^{\mathrm{Ab}}$ & $5.42 \pm 0.01^{\mathrm{Ab}}$ & $5.42 \pm 0.01^{\mathrm{Ab}}$ \\
\hline & 4 & $5.41 \pm 0.01^{\mathrm{Cb}}$ & $5.43 \pm 0.01^{\mathrm{Bb}}$ & $5.43 \pm 0.01^{\mathrm{Bab}}$ & $5.45 \pm 0.01^{\mathrm{Aa}}$ \\
\hline & 6 & $5.41 \pm 0.00^{\mathrm{Cb}}$ & $5.43 \pm 0.01^{\mathrm{Ab}}$ & $5.42 \pm 0.01^{\mathrm{ABb}}$ & $5.42 \pm 0.01^{\mathrm{BCb}}$ \\
\hline & 8 & $5.44 \pm 0.01^{\mathrm{Aa}}$ & $5.45 \pm 0.01^{\mathrm{Aa}}$ & $5.45 \pm 0.01^{\mathrm{Aa}}$ & $5.45 \pm 0.01^{\mathrm{Aa}}$ \\
\hline \multirow{5}{*}{$\begin{array}{l}\text { Soluble solid } \\
\text { ( }{ }^{\circ} \text { Brix) }\end{array}$} & 0 & $10.0 \pm 0.0^{\mathrm{Aa}}$ & $10.0 \pm 0.0^{\mathrm{Aab}}$ & $10.0 \pm 0.0^{\mathrm{Aa}}$ & $10.0 \pm 0.0^{\mathrm{Aa}}$ \\
\hline & 2 & $10.0 \pm 0.0^{\mathrm{Aa}}$ & $10.0 \pm 0.0^{\mathrm{Aab}}$ & $10.0 \pm 0.1^{\mathrm{Aa}}$ & $10.0 \pm 0.0^{\mathrm{Aa}}$ \\
\hline & 4 & $9.9 \pm 0.1^{\mathrm{Ab}}$ & $10.0 \pm 0.1^{\mathrm{Ab}}$ & $10.0 \pm 0.0^{\mathrm{Aa}}$ & $9.9 \pm 0.1^{\mathrm{Ab}}$ \\
\hline & 6 & $10.0 \pm 0.0^{\mathrm{Aa}}$ & $10.0 \pm 0.0^{\mathrm{Aab}}$ & $10.0 \pm 0.0^{\mathrm{Aa}}$ & $10.0 \pm 0.0^{\mathrm{Aa}}$ \\
\hline & 8 & $10.0 \pm 0.0^{\mathrm{Aa}}$ & $10.1 \pm 0.1^{\mathrm{Aa}}$ & $10.1 \pm 0.1^{\mathrm{Aa}}$ & $10.0 \pm 0.0^{\mathrm{Aa}}$ \\
\hline
\end{tabular}

${ }^{1)}$ All values are expressed as mean $\pm \mathrm{SD}$ of triplicate determinations.

2)A-D Means within row with different superscripts are significantly different $(\mathrm{p}<0.05)$.

${ }^{3) a-d}$ Means within column with different superscripts are significantly different $(p<0.05)$. 
Table 2. Changes in Hunter's color value of chaga mushroom extract during storage

\begin{tabular}{|c|c|c|c|c|c|}
\hline & $\begin{array}{l}\text { Storage period } \\
\text { (week) }\end{array}$ & $\mathrm{L}^{1)}$ & $\mathrm{a}$ & $\mathrm{b}$ & $\Delta \mathrm{E}$ \\
\hline & 0 & $\left.4.19 \pm 0.22^{2) \mathrm{a} 3}\right)$ & $-0.03 \pm 0.02^{\mathrm{a}}$ & $-0.32 \pm 0.12^{\mathrm{ab}}$ & - \\
\hline \multirow{4}{*}{ Control $^{4)}$} & 2 & $4.07 \pm 0.13^{\mathrm{a}}$ & $-0.03 \pm 0.02^{\mathrm{a}}$ & $-0.17 \pm 0.13^{\mathrm{b}}$ & $0.20 \pm 0.08^{\mathrm{a}}$ \\
\hline & 4 & $4.03 \pm 0.03^{\mathrm{a}}$ & $-0.05 \pm 0.05^{\mathrm{a}}$ & $-0.30 \pm 0.25^{\mathrm{ab}}$ & $0.29 \pm 0.15^{\mathrm{a}}$ \\
\hline & 6 & $4.15 \pm 0.09^{\mathrm{a}}$ & $-0.05 \pm 0.04^{\mathrm{a}}$ & $-0.32 \pm 0.10^{\mathrm{a}}$ & $0.24 \pm 0.14^{\mathrm{a}}$ \\
\hline & 8 & $4.20 \pm 0.07^{\mathrm{a}}$ & $-0.04 \pm 0.03^{\mathrm{a}}$ & $-0.32 \pm 0.25^{\mathrm{b}}$ & $0.21 \pm 0.03^{\mathrm{a}}$ \\
\hline \multirow{4}{*}{ Sunlight ${ }^{5)}$} & 2 & $3.95 \pm 0.15^{\mathrm{a}}$ & $-0.02 \pm 0.01^{\mathrm{a}}$ & $-0.13 \pm 0.08^{b}$ & $0.31 \pm 0.16^{\mathrm{a}}$ \\
\hline & 4 & $4.24 \pm 0.46^{\mathrm{a}}$ & $-0.04 \pm 0.03^{\mathrm{a}}$ & $-0.37 \pm 0.18^{\mathrm{ab}}$ & $0.44 \pm 0.27^{\mathrm{a}}$ \\
\hline & 6 & $4.25 \pm 0.27^{\mathrm{a}}$ & $-0.06 \pm 0.03^{\mathrm{a}}$ & $-0.53 \pm 0.02^{\mathrm{ab}}$ & $0.24 \pm 0.08^{\mathrm{a}}$ \\
\hline & 8 & $4.09 \pm 0.16^{\mathrm{a}}$ & $-0.02 \pm 0.01^{\mathrm{a}}$ & $-0.21 \pm 0.13^{\mathrm{ab}}$ & $0.15 \pm 0.05^{\mathrm{a}}$ \\
\hline
\end{tabular}

${ }^{1)} \mathrm{L}$, measures lightness and varies from 100 for perfect white to zero black; a, measures redness when plus and greenness when minus; $b$, measures yellowness when plus and blueness when minus; $\Delta \mathrm{E}, \sqrt{\Delta L^{2}+\Delta a^{2}+\Delta b^{2}}$, color difference.

${ }^{2)}$ All values are expressed as mean $\pm \mathrm{SD}$ of triplicate determinations.

${ }^{3) a-d}$ Means within column with different superscripts are significantly different $(p<0.05)$.

${ }^{4}$ Storage in darkness for use as control.

${ }^{5}$ Storage under sunlight.

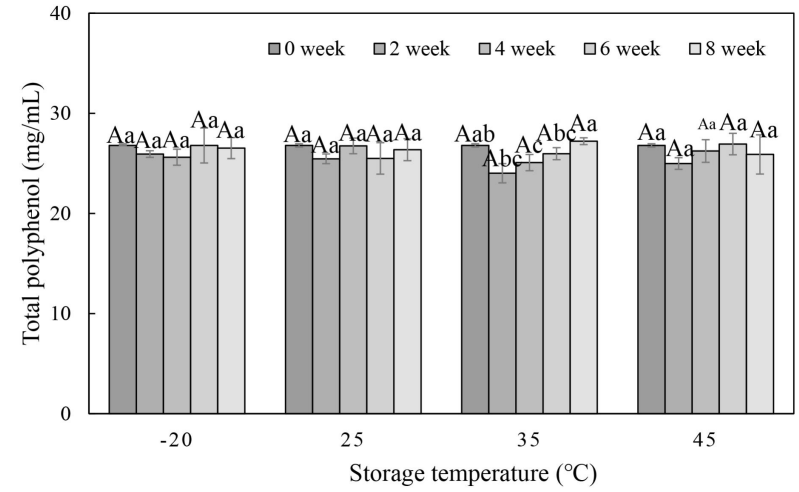

Fig. 1. Changes in total polyphenol content of chaga mushroom extract during storage.

Data are expressed as mean \pm SD of triplicate determinations.

${ }_{\mathrm{A}-\mathrm{D}}$ Means with different superscripts within the same storage period are significantly different $(\mathrm{p}<0.05)$.

${ }^{\mathrm{a}-\mathrm{d}}$ Means with different superscripts within the same storage temperature are significantly different.

함량을 보였다. 반면, 차가버섯에 20 배의 메탄올을 첨가하고 24시간 추출한 후 분말화한 시료의 총폴리페놀 함량이 209 $\mathrm{mg} / \mathrm{g}$ 으로 측정되어 본 연구의 결과와 다소 상이한 결과임을 알 수 있었다(Qi 등, 2013). 본 실험에서 저장 온도가 증가하 여도 총폴리페놀 함량은 유의적인 변화를 나타내지 않았는 데, 이는 $\operatorname{Kim}(2009)$ 이 식물성 폴리페놀의 열안정성에 대한 보고와 관련이 있는 것으로 확인되었다. Choi 등(2017)은 오 미자 음료의 저장에서 총페놀 함량은 저장 16 주까지는 큰 변
화가 없었다고 보고하였는데, 이는 본 실험에서 8 주 동안 저 장된 차가버섯 추출물의 폴리페놀 화합물이 안정하였다는 결 과를 잘 뒷받침해 주었다.

또한, 저장 온도 및 기간에 따라 항산화 활성의 변화를 확 인하기 위하여 차가버섯 추출물을 $1,000 \mathrm{ppm}$ 농도로 조제하 여 $\mathrm{DPPH}$ 를 이용한 라디칼 소거능을 측정해 본 결과, $-20^{\circ} \mathrm{C}$ 보관에서 저장 기간에 따라 유의적인 차이를 나타나지 않은 반면, $25^{\circ} \mathrm{C}$ 이상 저장 조건에서는 초기 $72.17 \%$ 에서 8 주 후 각각 $71.42 \%\left(25^{\circ} \mathrm{C}\right), 71.38 \%\left(35^{\circ} \mathrm{C}\right)$ 및 $71.03 \%\left(45^{\circ} \mathrm{C}\right)$ 로 각각 나타나 유의적인 감소로 확인되었지만( $\mathrm{p}<0.05)$ 그 변화 폭이 작았다(Fig. 2). ABTS를 이용한 양이온 라디칼 소거능 측정 결과에서는 차가버섯 추출물의 초기 항산화력은 $81.44 \%$ 이었 고, $-20^{\circ} \mathrm{C}$ 저장 8 주 경과 후에는 $80.38 \%$ 로 나타나 유의적인 변화는 없는 것으로 확인되었다( $\mathrm{p}>0.05)$. 반면 $25^{\circ} \mathrm{C}, 35^{\circ} \mathrm{C}$ 및 $45^{\circ} \mathrm{C}$ 보관에서는 8 주 경과 후 각각 $76.24 \%, 75.61 \%$ 및 $75.02 \%$ 로 항산화력이 각각 $6.4 \%, 7.1 \%$ 및 $7.9 \%$ 감소하여 온도가 증가할수록 항산화력이 유의적으로 감소함을 확인하 였다 $(\mathrm{p}<0.05)$. 상기 두 가지 방법의 항산화력을 비교해 보면, $\mathrm{DPPH}$ 법에 의해 측정한 항산화력은 $45^{\circ} \mathrm{C}$ 이내의 범위에서 저장온도가 증가하였을 때 항산화력의 변화폭이 크지 않은 반면, $\mathrm{ABTS}$ 법에 의하면 저장온도의 증가에 따라 항산화력 의 유의적인 감소가 있는 것으로 나타났다. 이것은 라디칼이 라는 점에서는 같으나 $\mathrm{DPPH}$ 법의 경우는 자유 라디칼이지만, $\mathrm{ABTS}$ 법은 양이온 라디칼이라는 점이 상이하고, 또한 페놀 성 물질의 종류에 따라 기질에 결합하는 능력이 차이에 기인 
(A)

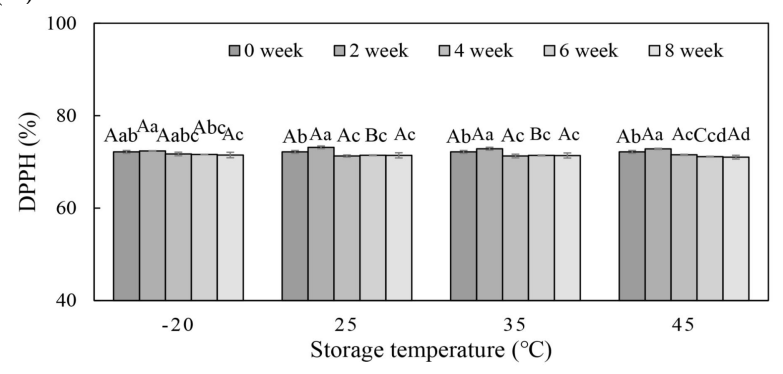

(B)

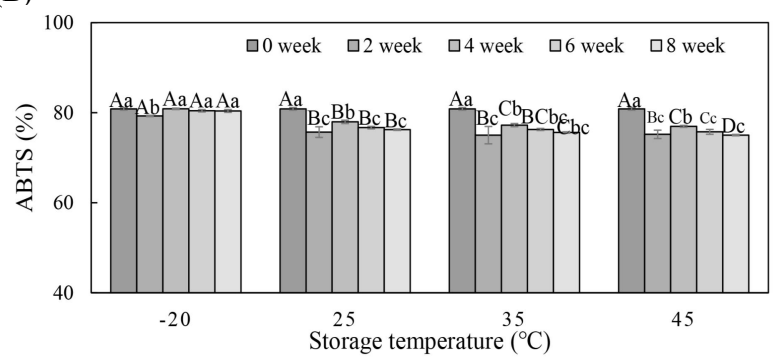

Fig. 2. DPPH radical scavenging activity (A) and ABTS radical scavenging activity (B) Antioxidant activities of chaga mushroom extract during storage.

Data are expressed as mean \pm SD of triplicate determinations.

${ }_{\mathrm{A}-\mathrm{D}}$ Means with different superscripts within the same storage period are significantly different $(\mathrm{p}<0.05)$.

${ }^{\mathrm{a}-\mathrm{d}}$ Means with different superscripts within the same storage temperature are significantly different.

하는 것으로 사료된다(Wang 등, 1998).

\section{추출물의 저장 중 베타글루칸 함량 변화}

버섯류의 베타글루칸( $\beta$-glucan)은 세포벽을 구성하면서 단 백질 혹은 기타 세포벽 성분과 결합한 형태로 존재한다. 이는 면역활성체의 기능, 항산화능 생체조직 재생과 치유 기능, 항 생, 항균, 항바이러스 및 대식세포를 자극하여 돌연변이 세포 를 인식하고 공격하는 항종양 효과가 있다고 보고되어 있으 며(Chang 등, 2001; Mizuno 등, 1998; Nakajima 등, 2002), 차가버섯의 항암 효능은 $\beta$-glucan의 함량에 주로 기인한다 (Shim 등, 2003). 버섯 $100 \mathrm{~g}$ 당 $\beta(1 \rightarrow 3) \mathrm{D}$ 글루칸 함량은 꽃 송이버섯 $43.6 \mathrm{~g}$, 잎새버섯 $15-20 \mathrm{~g}$, 영지버섯 8-15 g, 송이버 섯 $18.1 \mathrm{~g}$ 에 존재하는 것으로 알려져 있다(Kajimura와 Suga, 2004; Mimura 등, 1997). 동결건조된 차가버섯 추출분말의 $\beta$-glucan 함량을 측정해본 결과 Fig. 3과 같이 $2.58 \mathrm{~g} / 100 \mathrm{~g}$ 으로 나타났다. $\operatorname{Kim}(2014)$ 의 연구에서는 차가버섯을 $75 \%$ 에탄올을 용매로 $80^{\circ} \mathrm{C}$ 에서 12 시간 추출하였을 때, $\beta$-glucan 함량이 $22.7 \mathrm{mg} / \mathrm{g}$ 으로 나타나, 본 연구결과와 비슷한 $\beta$ glucan 함량을 보였다. 본 실험에서 저장 8 주 후 각 온도에서 $\beta$-glucan 함량을 비교해 본 결과, 각각 $2.49,2.45,2.48,2.36$

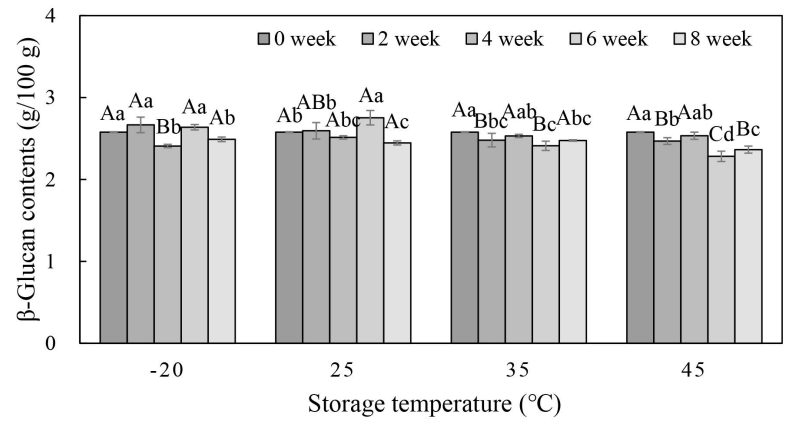

Fig. 3. Changes in $\beta$-glucan content of chaga mushroom extract during storage.

$\beta$-glucan $(\mathrm{g} / 100 \mathrm{~g})=$ Total glucan $(\mathrm{g} / 100 \mathrm{~g})$ - $\alpha$-glucan $(\mathrm{g} / 100 \mathrm{~g})$. Data are expressed as mean \pm SD of triplicate determinations.

${ }^{A-D}$ Means with different superscripts within the same storage period are significantly different $(p<0.05)$.

${ }^{\text {a-d }}$ Means with different superscripts within the same storage temperature are significantly different.

$\mathrm{g} / 100 \mathrm{~g}$ 으로 차가버섯 추출물의 저장기간에 따른 변화는 크지 않았으나, 저장 온도가 높은 $35,45^{\circ} \mathrm{C}$ 조건에서는 저장 6 주부 터 함량이 유의적으로 감소하는 경향을 보였다 $(\mathrm{p}<0.05)$. 이는 액상의 버섯 추출물의 경우, $35^{\circ} \mathrm{C}$ 이상의 조건에서는 6 주 이 후 $\beta$-glucan 함량이 7-8\% 정도 감소되는 것으로 확인되었으 므로, 저장 중 성분 안정성 확보를 위해서는 가급적 저온으로 유지하는 것이 바람직한 것으로 나타났다.

\section{추출물의 저장 중 베툴린 함량 변화}

베툴린은 주로 히말라야 자작나무 껍질에서 발견되는 triterpene 성분으로 수용성이 매우 낮아 초임계 이산화탄소 추출법이나 헥산과 에틸아세테이트 혼합용매를 사용한 초음 파 추출이 효과적이다(Chen 등, 2009; Jeromenok 등, 2011). 본 연구에서는 차가버섯을 1 차 열수추출한 후 2 차 $50 \%$ 주정 을 이용한 추출로 베툴린의 함량이 약 $12 \mu \mathrm{g} / \mathrm{mL}$ 로 낮게 측정 되었다. Alhazmi(2017)에 따르면 차가버섯을 $95 \%$ 에탄올로 3 시간 환류추출하였을 때 베툴린 함량이 $5.44-68.85 \mu \mathrm{g} / \mathrm{g}$ 으 로 본 실험과 비슷한 결과를 보였고, 전처리를 통해 $918 \mu \mathrm{g} / \mathrm{g}$ 까지 증가한다고 보고되었다. 저장 시료 중에는 $-20^{\circ} \mathrm{C}$ 조건에 서 베툴린 함량의 변화가 없는 반면, $35^{\circ} \mathrm{C}$ 이상의 보관조건에 서는 2 주차부터 베툴린 함량이 약 $19 \%$ 의 유의적 감소를 나 타내면서 $(\mathrm{p}<0.05)$ 저장 8 주까지는 유사한 수준을 나타내었다 (Fig. 4).

이상의 결과에서 차가버섯 추출물의 베툴린 함량은 $\beta$ glucan에 비해 저장 온도와 기간에 영향을 더 받게 됨을 알 수 있었다. 이상의 결과를 고려할 때 차가버섯 추출물에 함유 된 기능성 성분은 $30^{\circ} \mathrm{C}$ 이상의 높은 온도에서 저장할 경우, 함량이 줄어들 수 있는 가능성이 확인되어 가급적 상온 이하 


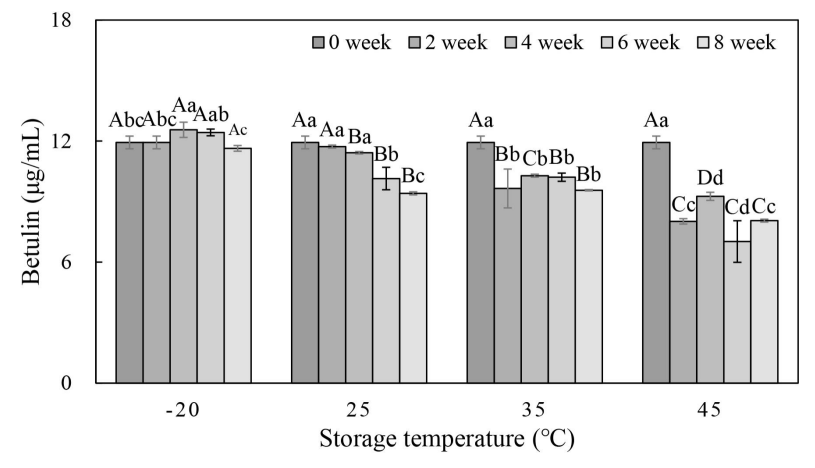

Fig. 4. Changes in betulin content of chaga mushroom extract during storage.

Data are expressed as mean \pm SD of triplicate determinations.

${ }^{\mathrm{a}-\mathrm{d}}$ Means with different superscripts within the same storage temperature are significantly different.

A-D Means with different superscripts within the same storage period are significantly different $(\mathrm{p}<0.05)$.

의 조건에 저장하는 것이 바람직하게 나타났다.

\section{추출물의 저장 중 미생물 생육}

차가버섯 추출물의 저장 기간 및 온도에 따른 미생물의 변 화는 Table 3 과 같다. 총세균과 대장균군은 8 주의 저장기간 동안 모든 온도군의 시료에서 불검출로 확인되어 미생물적 품질이 매우 안전한 것으로 확인되었다. 이는 차가버섯 추출 물을 $95^{\circ} \mathrm{C}$ 이상에서 10 분간 살균하였으므로 저장 중에 미생 물의 생육이 나타나지 않은 것으로 판단되며, 이로써 차가버 섯 액상추출물의 8주 내외의 저장 유통에는 미생물적으로 문 제가 없을 것으로 사료된다. 이 같은 결과는 Park 등(2014)의 $80^{\circ} \mathrm{C}$ 에서 10 분간 살균한 음료는 저장기간 중 미생물이 검출 되지 않았다는 보고를 잘 뒷받침해 주었다.

\section{요 약}

본 연구는 차가버섯 추출물의 저장안정성을 확인하고자 여러 저장온도 $\left(-20,25,35,45^{\circ} \mathrm{C}\right)$ 에서 8 주 동안 보관하면서 이화학적 성분 및 품질안정성을 측정하였다. 정제수와 $50 \%$ 주정으로 추출한 후 $95^{\circ} \mathrm{C}, 10$ 분간 살균한 추출물의 $\mathrm{pH}$ 는 저 장 기간 중 $\mathrm{pH}$ 5.33에서 $\mathrm{pH}$ 5.38-5.45 수준으로 다소 증가되 었고 $(\mathrm{p}<0.05)$, 가용성 고형분 함량은 저장온도와 기간에 관 계없이 일정하게 유지되었다. 추출물의 색도 $(\mathrm{L}, \mathrm{a}, \mathrm{b})$ 는 직사 광선 조건에서도 유의적 차이를 보이지 않았다. 추출물의 총 폴리페놀 함량 $(26 \mathrm{mg} / \mathrm{mL})$ 은 저장온도에 따라 다소 증감하였 으나, 저장 8주 동안 유의미한 변화를 보이지 않았다. 추출물 의 항산화력을 측정한 $\mathrm{DPPH}$ 실험에서는 모든 실험구에서 $70 \%$ 이상의 라디칼 소거능을 나타내었다. 반면, $\mathrm{ABTS}$ 를 이 용한 양이온 라디칼 소거능 측정에서는 저장 8 주 후 저장온 도 $25,35,45^{\circ}$ C에서 항산화력이 각각 $6.4,7.1,7.9 \%$ 감소하 여 저장온도에 따른 항산화활성의 유의적인 차이가 확인되었 다 $(\mathrm{p}<0.05)$. 추출물의 $\beta$-glucan 함량은 초기 $2.58 \%$ 수준으로 저장온도 $-20^{\circ} \mathrm{C}$ 와 $25^{\circ} \mathrm{C}$ 에서는 안정하였으나, $35^{\circ} \mathrm{C}$ 와 $45^{\circ} \mathrm{C}$ 의 높은 온도에서는 저장 6 주차에 유의적인 감소를 보였다 $(\mathrm{p}<0.05)$. 베툴린 함량 $(12 \mu \mathrm{g} / \mathrm{mL})$ 역시 $-20^{\circ} \mathrm{C}$ 와 $25^{\circ} \mathrm{C}$ 저장온 도에서는 비교적 안정하였다. 차가버섯 추출물은 여러 온도 에서 8 주 동안 저장하였으나, 총세균과 대장균군이 검출되지 않아 미생물적으로 안정하였다. 이상의 결과, 차가버섯 추출 물은 살균처리를 통해 미생물적 품질안정성을 확보할 수 있었 으며, $-20^{\circ} \mathrm{C}$ 와 $25^{\circ} \mathrm{C}$ 에서는 8 주 동안 이화학적 및 기능성 성분 이 안정하였다. 하지만 $35^{\circ} \mathrm{C}$ 이상의 고온에서는 베툴린 함량, $\beta$-glucan 함량, 항산화성의 순으로 저장안정성이 낮은 것으로 확인되어 이에 대한 구체적인 연구가 필요하다고 사료된다.

Table 3. Microbial counts of chaga mushroom extract during storage at different temperatures

\begin{tabular}{cccccc}
\hline & $\begin{array}{c}\text { Storage period } \\
\text { (week) }\end{array}$ & -20 & 25 & 35 & 45 \\
\cline { 3 - 6 } & 2 & $\mathrm{ND}^{1)}$ & $\mathrm{ND}$ & $\mathrm{ND}$ & $\mathrm{ND}$ \\
& 4 & $\mathrm{ND}$ & $\mathrm{ND}$ & $\mathrm{ND}$ & $\mathrm{ND}$ \\
$\begin{array}{c}\text { Aerobic bacteria } \\
(\mathrm{CFU} / \mathrm{mL})\end{array}$ & 6 & $\mathrm{ND}$ & $\mathrm{ND}$ & $\mathrm{ND}$ & $\mathrm{ND}$ \\
& 8 & $\mathrm{ND}$ & $\mathrm{ND}$ & $\mathrm{ND}$ & $\mathrm{ND}$ \\
\hline & 2 & $\mathrm{ND}$ & $\mathrm{ND}$ & $\mathrm{ND}$ & $\mathrm{ND}$ \\
Coliforms & 4 & $\mathrm{ND}$ & $\mathrm{ND}$ & $\mathrm{ND}$ & $\mathrm{ND}$ \\
$(\mathrm{CFU} / \mathrm{mL})$ & 6 & $\mathrm{ND}$ & $\mathrm{ND}$ & $\mathrm{ND}$ & $\mathrm{ND}$ \\
& 8 & $\mathrm{ND}$ & $\mathrm{ND}$ & $\mathrm{ND}$ & $\mathrm{ND}$ \\
\hline
\end{tabular}

${ }^{1)} \mathrm{ND}$ means not detected. 


\section{Conflict of interests}

The authors declare no potential conflict of interest.

\section{ORCID}

$\begin{array}{ll}\text { Da-Hyun Park } & \text { https://orcid.org/0000-0002-7525-6647 } \\ \text { Yong-Jin Jeong } & \text { https://orcid.org/0000-0002-5712-2856 }\end{array}$

\section{References}

Alhazmi H. Extraction of phytochemicals betulin and betulinic acid from the chaga mushroom and their effect on MCF-7 Cells. MS Thesis, Lakehead University, Canada, p 39-41 (2017)

An CS, Jin HL, Jeon YH, Bak JP, Kim JD, Yoon JH, Lim BO. Immunoregulatory effects of water extracts of Inonotus obliquus in carbon tetrachloride-induced liver damage animal model. Korean J Medicinal Crop Sci, 18, 1-8 (2010)

Bhullar JS, Dhillon BS, Randhawa JS. Effect of wrappers on the storage of kinnow mandarin. J Res Punjab Agric Univ, 22, 663-666 (1985)

Blois MS. Antioxidant determinations by the use of a stable free radical. Nature, 181, 1199-1200 (1958)

Chae KY, Kim JE, Park SN. Antibacterial activity of Hippophae rhamnoides leaf extract and the stability of a cream with the extract. Korean J Microbiol Biotechnol, 40, 43-49 (2012)

Chang HL, Chao GR, Chen CC, Mau JL. Non-volatile taste components of Agaricus blazei, Antrodia camphorata and Cordyceps militaris mycelia. Food Chem, 74, 203-207 (2001)

Chen QH, Fu ML, Liu J, Zhang HF, He GQ, Ruan H. Optimization of ultrasonic-assisted extraction (UAE) of betulin from white birch bark using response surface methodology. Ultrason Sonochem, 16, 599-604 (2009)

Choi EY, Yu JH, An HJ. Quality properties of omija beverage based on the storage container and storage temperature. J Korean Soc Food Sci Nutr, 46, 13661372 (2017)

Cui Y, Kim DS, Park KC. Antioxidant effect of Inonotus obliquus. J Ethnopharmacol, 96, 79-85 (2005)

Folin O, Dennis W. On phosphotungstic-phosphomolybdic compounds as color reagents. J Biol Chem, 12, 239-243 (1912)

Fujioka T, Kashiwada Y, Kilkuskie RE, Cosentino LM, Ballas LM, Jiang JB, Janzen WP, Chen IS, Lee KH. Anti-AIDS agents, 11. Betulinic acid and platanic acid as anti-HIV principles from Syzigium claviflorum, and the anti-HIV activity of structurally related triterpenoids. J Nat Prod, 57, 243-247 (1994)

Gong Y, Raj KM, Luscombe CA, Gadawski I, Tam T, Chu J, Gibson D, Carlson R, Sacks SL. The synergistic effects of betulin with acyclovir against herpes simplex viruses. Antiviral Reseasrch, 64, 127-130 (2004)

Holonec L, Ranga F, Crainic D, Truta A, Socaciu C. Evaluation of betulin and betulinic acid content in birch bark from different forestry areas of western carpathians. Not Bot Horti Agrobo, 40, 99-105 (2012)

Jeromenok J, Bohlmann W, Antonietti M, Weber J. Intrinsically microporous polyesters from betulin-toward renewable materials for gas separation made from birch bark. Macromol Rapid Commun, 32, 1846-1851 (2011)

Kahlos K. Inonotus Obliquus (Chaga Fungus): In Vitro Culture and the Production of Inotodiol, Sterols and Other Secondary Metabolites. Medicinal and Aromatic Plants VI, Springer, Berlin, Heidelberg, p 179-198 (1994)

Kajimura M, Suga T. Research and development of functional food including superfine $\beta$-glucan (Lentinan). Chemical Industry, 55, 466-475 (2004)

Kim BB, Kim MS, Hyun CK. Suppression of adiposity and improvement of fat metabolism in high-fat diet-induced obese mice treated with an Inonotus obliquus extract. Kor J Pharmacogn, 47, 172-178 (2016)

Kim JC. Determination of extraction condition of bioactive compounds from chaga mushroom (Inonotus obliquus) by response surface methodology. MS Thesis, Seoul National University, Korea (2014)

Kim JC, Yi HC, Lee KU, Hwang KT, Yoo GC. Optimization of the extraction of bioactive compounds from chaga mushroom (Inonotus obliquus) by the response surface methodology. Korean J Food Sci Technol, 47, 233-239 (2015)

Kim PR, Ko SK, Pyo MY. Effects of hot water extract of chaga mushroom on the proliferation and cytokines production of mouse splenocytes in vitro. Yakhak Hoeji, 
54, 187-191 (2010)

Kim YJ. Evaluation of antioxidant activity and thermal stability of plant polyphenols. Biomater Res, 13, 30-36 (2009)

Lee SO, Kim MJ, Kin DG, Choi HJ. Antioxidative activities of temperature-Stepwise water extracts from Inonotus obliquus. J Korean Soc Food Sci Nutr, 34, 139-147 (2005)

Liang L, Zhang Z, Wang H. Antioxidant activities of extracts and subfractions from Inonotus obliquus. Int $\mathrm{J}$ Food Sci Nutr, 60, 175-184 (2009)

Mimura T, Ohno N, Miura NN, Shimada S, Yadomae T. Inactivation of a particle $\beta$-glucan by proteins in plasma and serum. Biol Pharm Bull, 20, 1103-1107 (1997)

Mizuno M, Morimoto M, Minato KI, Tsuchida H. Polysaccharides from Agaricus blazei stimulate lymphocyte T-cell subsets in mice. Biosci Biotechnol Biochem, 62, 434-437 (1998)

Moon BH, Lee WC. Studies on the anti-cancer activity of chaga mushroom extract. J Korean Oriental Med, 30, 1-12 (2009)

Myung JE, Hwang IK. Functional components and antioxidative activities of soybean extracts. Korea Soybean Digest, 25, 23-29 (2008)

Nakajima A, Ishida T, Koga M, Takeuchi T, Mazda O, Takeuchi M. Effect of hot water extract from Agaricus blazei Murill on antibody-producing cells in mice. Int immunopharmacol, 2, 1205-1211 (2002)

Park JH, An DS, Lee DS, Park EJ. Prediction of shelf-life of sea tangle drink. J Korean Soc Food Sci Nutr, 43, 784-790 (2014)

Pisha E, Chai H, Lee IS, Chagwedera TE, Farnsworth NR, Cordell GA, Beecher CWW, Fong HHS, Kinghorn AD, Brown DM, Wani MC, Wall ME, Hieken TJ, Gupta TK, Pezzuto JM. Discovery of betulinic acid as a selective inhibitor of human melanoma that functions by induction of apoptosis. Nat Med, 1, 1046-1051 (1995)

Qi Y, Zhao X, Lim YI, Park KY. Antioxidant and anticancer effects of edible and medicinal mushrooms. $\mathrm{J}$ Korean Soc Food Sci Nutr, 42, 655-662 (2013)

Shim JS, Lee BH, Kang SJ. The Substance and Application of Chaga Mushroom. The International Agricultural Development Institute, Seoul, Korea, p 10-35 (2003)

Song HY, Lee DJ, Lee BE. Studies on the anti-pulmonary tuberculosis of Inonotus obliquus. J Mushrooms, 9, 190-193 (2011)

Tabata K, Ito W, Kojima T, Kawabata S, Misaki A. Ultrasonic degradation of schizophyllan, an antitumor polysaccharide produced by Schizophyllum commune fries. Carbohydr Res, 89, 121-135 (1981)

Wang M, Li J, Rangarajan M, Shao Y, LaVoie EJ, Huang TC, Ho CT. Antioxidative phenolic compounds from sage (Salvia officinalis). J Agric Food Chem, 46, 48694873 (1998)

Yamamoto T, Yamashita T, Tsubura E. Inhibition of pulmonary metastasis of Lewis lung carcinoma by a glucan, Schizophyllan. Invasion Metastasis, 1, 71-84 (1981) 